\title{
Формирование флористических лесных комплексов юга Сибири
}

\section{Formation of floristic forest complexes of the South of Siberia}

\author{
Харитонцев Б. С. \\ Haritontsev B. S. \\ Тобольская комплексная научная станщия УрО РАН, г. Тобольск, Россия. E-mail: xaritoncev52@mail.ru \\ Tobolsk complex scientific station OURO RAHN, Tobolsk, Russia
}

\begin{abstract}
Peферат. Леса Сибири разнообразны по фитоценотическим признакам и генезисным особенностям. Для каждого типа леса характерны свои доминанты с набором верных видов. Подобные сочетания формировались в течение длительных временных отрезков в лесные комплексы. На юге Сибири от Зауралья до Байкала можно выделить комплексы остепненных сосняков, западносибирских березняков и липняков, южносибирских реликтовых липняков, кедрово-пихтовых и лиственично-сосновых лесов. Присутствие в них эндемиков (реже реликтов) и групп верных видов подчеркивает оригинальность каждого из комплексов. Экологическая специфичность комплексов обуславливает отбор видов, как автохтонных, так и мигрантов при формировании комплекса.
\end{abstract}

Ключевые слова. Леса Сибири, лесные комплексы, эндемики, генезис.

Summary. Forests of Siberia are diverse in phytocenotic and genesis features. The dominants with a set of true species characterize each type of the wood. Such combinations have been developing during the long time into the forest complexes. In the south of Siberia from the Trans-Ural region to Baikal it is possible to allocate complexes of steppe pine forests, the West Siberian birch forest and linden forest, the South Siberian relic linden forest, cedar-fir and larch-pine forests. Presence of endemics (is rarer than relicts) and groups of true species emphasizes originality of each complex. The ecological specificity of complexes causes selection of species, both autochthonic, and migrants when complex is developing.

Key words. Forests of Siberia, forest complexes, endemics, genesis.

Территория юга Сибири включает часть Западной Сибири (южнее северной границы березовых лесов) и горные области южной Сибири до Байкала. На данной территории сформировались лесные комплексы: равнинные - западносибирский комплекс остепненных сосняков на песках, березняков и тилетный западносибирский; горные (реликтовые) - тилетный южносибирский черневой таежный и светлохвойный южносибирский. Основным признаком выделения подобных комплексов является генезисный, отражающий особенности формирования их флоры. Разнообразие ассоциаций лесных комплексов Сибири проанализировано в сводке (Зеленая книга Сибири, 1996). Кроме этого каждый из комплексов имеет свои географические, экологические, фитоценотические (виды-доминанты, постоянные виды, верные виды) особенности. Западносибирский сосновоостепненный комплекс на песках отличается дизъюнктивным ареалом из западной (пески бассейна Тобола) и восточной (ленточные боры) частей. Комплекс занимает песчаные массивы высоких террас рек и долины древних стоков. Доминант Pinus sylvestris L., развит подлесок часто из степных кустарников, травяной ярус с тремя подъярусами и обилием псаммофитов. Эндемики из родов Pilosella, Hieracium, Thymus. Характерен аспект весенних эфемеров и эфемероидов.

Западносибирский комплекс березняков на суглинках располагается в южной части западносибирской равнины в пределах небольших дренированных грив при чередовании засоленных и заболоченных понижений. Доминант Betula pendula Roth., кустарниковый ярус развит слабо, травяной ярус отличается сочетанием бореальных (Rubus saxatilis L.) и лесостепных (Brachypodium pinnatum (L.) Beauv.) видов. Эндемики: Geranium bifolium Patrin ex DC. 
Южносибирский горнолиственичный комплекс располагается на юге Западной Сибири и Северной Монголии, занимает северо-западные или северо-, юго-восточные экспозиции на высоте 800 1200 м, является эталоном коренной растительности подтаежного лесостепного пояса - Алтае-Саянской горной страны. Доминант Larix sibirica Ledeb., кустарниковый ярус развит слабо (Spiraea chamaedryfolia L. и др.), травяной ярус с несколькими подъярусами. В комплексе произрастают алтае-саянские эндемики Vicia lilacina Ledeb., Aconitum krylovii Steinb.

Южносибирский кедрово-пихтовый (черневой) комплекс располагается в ультрогумидном циклоническом климатическом секторе Алтае-Саянской горной страны, занимает в основном склоны северной ориентации на высотах 350-900 м. Доминанты Pinus sibirica Du Tour, Picea obovata Ledeb., Abies sibirica Ledeb. Ярус кустарников хорошо выражен. Травяной ярус подразделяется на подъяруса (3 и более). Содержит эндемичные Алтае-Саянские виды: Brunnera sibirica Steven и др. Характерна весенняя стадия эфемероидов: Corydalis bracteata (Steph. ex Willd.) Pers. и др.

Южносибирский липово-реликтовый комплекс дислоцирован в черневом подпоясе Горной Шории, состоит из отдельных участков. Комплекс занимает склоны преимущественно южной экспозиции на высоте 300-500 м. Эталон коренной растительности Алтае-Саянской горной области (Положий, Крапивкина, 1985. Доминант Tilia sibirica Bayer. Кустарниковый ярус представлен Daphne mezereum L. и др. Травяной ярус подразделяется на три подъяруса, включает 23 вида неморальных третичных реликта. Развивается стадия весенних эфемероидов: Anemone altaica Fisch. ex C.A. Mey., Erythronium sibiricum (Fisch. et C.A. Mey.) Krylov и др. Присутствуют эндемичные алтае-саянские виды (Крапивкина, 1996): Anemone caerulea DC. и др.

Западносибирский тилетный комплекс расположен в Зауралье в пределах южной тайги и подтайги Тюменской области и по Иртышу в Омской области до Тары. По Иртышу поднимается до Ханты-Мансийска. Южная граница проходит к северу от 56² 30' по точкам Екатеринбург-Тюмень-Тара (Науменко, 2008). В долине Иртыша комплекс занимает склоны южной экспозиции, на плакоре - возвышенные участки. Доминант Tilia cordata Mill., часто образует ассоциации Tilia cordata-Pinus sylvestris. Кустарниковый ярус не развит. Травяной ярус из трех подъярусов. Заметную роль в травяном покрове выполняют Carex macroura Meinsh., Carex digitata L.

По генезису все комплексы автохтонные это подтверждается произрастанием в них эндемичных видов, а также присутствием в каждом из них групп видов, характерных только для данного комплекса. Эндемичные виды в определенной мере отражают генезисные отношения с комплексом, от которого данные эндемики произошли. Например, Stipa pennata ssp. sabulosa (P. Smirn.) Tzvelev - подвид комплекса сосняков остепненных имеет связи с Stipa pennata L. Несущественное различие Stipa pennata ssp. sabulosa (P. Smirn.) Tzvelev от родительского вида подтверждают одновременно и относительную молодость комплекса сосняков остепненных и его связи со степями Европы и Казахстана. Эндемики Bromopsis austrosibirica Peschkova, Elymus ircutensis Peschkova, имеющие криоаридные восточносибирские генезисные связи характеризуют влияние восточносибирских криоаридных комплексов на генезис южносибирского горнолиствиничного комплекса. Некоторые эндемики занимают изолированное таксономическое положение и в то же время могут произрастать в нескольких комплексах. Такой дуализм объясняется одновременностью формирования этих комплексов, но разделенных экологически. Важное значение имеют так же реликты в выяснении вопросов генезиса комплекса. Большое число реликтов (23 вида) (Крапивкина, 1996) объясняется третичной природой комплекса липняков реликтовых по сравнению, с остальными имеющими меньшее число реликтовых видов или даже их отсутствие.

Особенности экологического ареала комплексов хорошо выявляются при сравнении экологических характеристик видов одного рода, так как в этом случае (исключается влияние) таксономический фактор (виды одного рода) однотипен для всех комплексов. В качестве примера можно взять род Festuca L. (Алексеев, 1990).

Festuca polesica Zapał. характерна для комплекса сосняков остепненных. Растения плотнодерновинные. Пластинки листьев жесткие, торчащие, цилиндрические со сплошным кольцом склеренхимы под нижним эпидермисом. Произрастает в Северном Казахстане, Восточной Европе и на юге Западной Сибири. 
Festuca altissima All. произрастает в южносибирском липово-реликтовом комплексе. Побеги невлагалищные, растения рыхлокустовые. Пластинки листьев плоские, сверху без ребер. Произрастают в Европе, Западной Азии, Южной Сибири, на Кавказе и Казахстанском Алтае. Festuca extremiorientalis Ohwi как и предыдущий вид произрастает в липняках горной Шории. По габитусу похожа на предыдущий вид, но имеет ареал дальневосточно-восточноазиатский. Два этих вида овсяниц отражают своеобразное формирование комплекса реликтовых липняков по сравнению с остальными лесными комплексами Сибири.

Festuca gigantea (L.) Vill. отмечена в комплексе кедрово-пихтовом. Растения рыхлокустовые, побеги невлагалищные, пластинки листьев плоские без ребер. К особенностям её ареала следует отнести произрастание наряду с Европой, Средней и Западной Азией, Южной Сибирью в Западных Гималаях. Более характерно для кедрово-пихтового комплекса, но может встречаться и в комплексе реликтовых липняков.

Festuca pseudosulcata Drobow вид характерен для Дальнего Востока и Южной Сибири. В последнем регионе она произрастает в комплексе лиственично-сосновом. Растения с внутривлагалищными побегами и вдоль сложенными листьями.

Festuca rupicola Heuff. чаще встречается по березнякам на юге Западной Сибири, в Европе и Средней Азии. Растения с внутривлагалищным возобновлением побегов.

Сравнивая особенности экологии и ареалов овсяниц с отдельными видами, характерными для каждого из лесных комплексов юга Сибири, можно констатировать следующие положения. Лесной липовый реликтовый комплекс формировался в оптимальной для липы влажных и теплых условиях. Он состоит из европейских и восточноазиатских видов (Festuca altissima, Festuca extremiorientalis), занимавших в третичное время непрерывную зону от Атлантического до Тихого океанов между $50^{\circ}$ с.ш. и $60^{\circ}$ с.ш. В плейстоцене зона была разорвана на 3 участка. Места разрывов соответствовали отрезкам, подвергшимся наибольшему влиянию климатических факторов плейстоцена: криогумидным в Западной Сибири и криоаридным в Восточной Сибири. Формирование пихтово-кедрового комплекса происходило в горных условиях Алтае-Саянской страны. Ареал Festuca gigantea частично совпадает с ареалом Festuca altissima, но имеет горное родство. Соответственно и его генезис происходил в более экстремальных условиях по сравнению с липовым реликтовым комплексом одновременно. Это подтверждается рецентным смешением Festuca gigantea между 2 комплексами. Экологические особенности Festuca polesica отражают механизм формирования сосновоостепненного комплекса, формирующегося в пределах накопления аллювиальных песчаных почв из ледниковых вод, перемещающихся в Арало-каспийский и черноморский бассейны. Этот процесс охватывал юг Западной Сибири, Северный Казахстан, центр и юг Восточной Европы. Ареал Festuca pseudosulcata охватывающий Южную Сибирь и Дальний Восток отражает место генезиса листвинично-соснового комплекса Южной Сибири. Формирование двух остальных лесных комплексов, присущих югу Западной Сибири (комплексы березняков и липняков) отражено особенностями ареалов видов осок Carex macroura Meinsh., Carex arnellii H. Christ. (Малышев, 1990). Оптимумареал Carex macroura расположен в горах Южной Сибири и на юге Западной Сибири. В западносибирском регионе Carex macroura типична для березняков. Это свидетельствует о горном доплейстоценовом их происхождении. В плейстоцене комплекс березняков распространился по Западно-Сибирской равнине. Ареал Carex arnellii совпадает также с доплейстоценовым (по происхождению) комплексом липняков Западной Сибири, в последствии ассимилированным потоком европейских тилетных видов.

\section{ЛИТЕРАТУРА}

Алексеев E. Б. Festuca L. - Овсяница // Флора Сибири. Роaceae (Gramineae) / Сост. Пешкова Г. А., Никифорова О. Д., Ломоносова М. Н. и др. - Т. 14. - Новосибирск: Наука. Сиб. отд-ние, 1990. - Т. 2 - С. 130-162. 
Зеленая книга Сибири. Редкие и нуждающиеся в охране растительные сообщества. - Новосибирск: Наука, 1996. - 396 c.

Малышев Л. И. Сагех L. - Осока. // Флора Сибири. Суреraceae / Сост. Малышев Л. И., Тимохина С. А., Бубнова С. В. и др. - Новосибирск: Наука, Сиб. отд-ние, 1990. - Т. 3. - С. 35-170.

Науменко Н. И. Флора и растительность Южного Зауралья. - Курган: Изд-во Курганского гос. ун-та, 2008. $512 \mathrm{c.}$

Положий А. В., Крапивкина Э. Д. Реликты третичных широколиственных лесов во флоре Сибири. - Томск: Изд-во Томского государственного ун-та, 1985. - 158 с. 